\title{
La lumière. Hélène Casella - francuska przyjaciółka Karola Szymanowskiego
}

Grzegorz Piotrowski

TEKSTY DRUGIE 2019, NR 1, S. 353-367

DOI: 10.18318/td.2019.1.24 | ORCID: 0000-0001-6488-2661

Nic [...] nie razi mnie bardziej, niż małostkowość...

„Największym naszym błędem - pisał Jarosław Iwaszkiewicz - jest niedocenianie ludzi, kiedy się ich jeszcze ma koło siebie. [...] Nie docenialiśmy Caselci, śmieliśmy się z niej, nudziła nas. A przecież cóż to był za człowiek, jaka mądrość życiowa, jaka kultura, jaka zdolność do uczuć. To był wielki, może jedyny nasz przyjaciel”. Zarazem: „ktoś najbliższy w Paryżu i najintymniejszy, quasi rodzina"3. Iwaszkiewiczowi wtórowała

1 Hélène Casella w liście do Karola Szymanowskiego z 26 października 1923 r. - K. Szymanowski Korespondencja. Pełna edycja zachowanych listów od i do kompozytora, zebr. i oprac. T. Chylińska, t. 2, 1920-1926, CZ. 1, Do 1923, PWM, Kraków 1994, s. 663.

2 J. Iwaszkiewicz Dzienniki 1911-1955, oprac. i przyp. A. i R. Papiescy, wstęp A. Gronczewski, Czytelnik, Warszawa 2007, s. 521.

3 W liście do żony z 30 marca 1926 r. - A. i J. Iwaszkiewiczowie Listy 1922-1926, oprac. M. Bojanowska, E. Cieślak, wstęp T. Burek, Czytelnik, Warszawa 1998, s. 540.
Grzegorz Piotrowski

- dr, muzykolog

i kulturoznawca, kierownik Katedry Kulturoznawstwa w Instytucie Badań nad Kulturą UG i wykładowca Akademii Muzycznej w Gdańsku. Ostatnio opublikował: Muzyka popularna. Nasłuchy i namysły (2016). Kontakt: peter_ kilbourn@op.pl 
żona Anna: „z Casellą jesteśmy tak blisko, naprawdę jest moją przyjaciółką, właściwie nie mam innej..."4.

„Kto to Caselcia?” - moglibyśmy zapytać retorycznie słowami Czesława Miłosza. I jego słowami wyjaśnić: „Ciągle o niej słyszało się w kołach młodych polskich muzyków. Stara Francuzka, po mężu Casella, opiekuńcza, wielu pomagała"5.

Hélène Casella (w polskich edycjach źródłowych i pracach biograficznych dotyczących kręgu Karola Szymanowskiego i Iwaszkiewicza wspominana raczej z nazwiskiem panieńskim: jako Kahn-Casella; posługiwała się zresztą obiema wersjami), rodowita paryżanka, należała do powszechnie znanych postaci w muzycznym świecie Paryża lat 20. i 30. ubiegłego stulecia. Była pianistką-akompaniatorką i korepetytorką, a także, w młodości, śpiewaczką - świetną, jak obie jej profesje ocenił były mąż Alfredo Casella, włoski kompozytor6. Udzielała prywatnych lekcji gry i czasem też - wcale nierzadko - występowała na estradzie, choć raczej w sytuacjach salonowego muzykowania niż koncertu w pełnym tego słowa znaczeniu, aczkolwiek akompaniowała np. Stanisławie Szymanowskiej na prestiżowym recitalu w Salle Pleyel, zorganizowanym przez Société musicale indépendante 2 lutego 1927 roku? . Wielokrotnie wykonywała też Mity Szymanowskiego ${ }^{8}$. Iwaszkiewicz w 1934 roku grę i śpiew prawie sześćdziesięcioletniej wówczas Heleny oceniał krytycznie. À propos planów wieczorku muzycznego w poselstwie polskim

4 W Dziennikach pod datą 16 września 1932 r. - A. Iwaszkiewiczowa Dzienniki i wspomnienia, do druku podała M. Iwaszkiewicz, oprac., przyp. i indeks P. Kądziela, Czytelnik, Warszawa 2000, S. 288 .

5 Cz. Miłosz, J. Iwaszkiewicz Portret podwójny. Wykonany z listów, wierszy, zapisków intymnych, wywiadów i publikacji, wybór, układ i red. B. Toruńczyk, oprac. i przyp. R. Papieski, Zeszyty Literackie, Warszawa 2011, s. 336.

6 A. Casella Music in My Time. The Memoirs of Alfredo Casella, transl. and ed. by S. Norton, University of Oklahoma Press, Norman 1955, s. 76.

7 Zob. komentarz Teresy Chylińskiej do listu Caselli do Iwaszkiewicza po 2 lutego 1927 r. - K. Szymanowski Korespondencja, t. 3, 1927-1931, cz. 1, 1927, 1928, PWM, Kraków 1997, s. 58. Szymanowska śpiewała sześć pieśni z Rymów dziecięcych, dwie z Pieśni miłosnych Hafiza oraz pierwsze ogniwo Pieśni muezina szalonego, a także utwory Debussy'ego, Milhauda i Tansmana.

8 "Jeszcze jestem cała rozgorączkowana tym, że wywołałam takie wrażenie Pańskim utworem. Pani Prunières [żona Henriego - przyp. G.P.] płakała, Alec [Alexander Stainert - amerykański kompozytor, przyjaciel Szymanowskiego - przyp. G.P.] był bardzo blady, a moja stara przyjaciółka-muzyczka [...] - była po prostu wstrząśnięta objawieniem takiej poezji" (Casella w liście do Szymanowskiego z 20 lutego 1924 r. - tamże, t. 2, cz. 2, Od 1924, s. 44). 
w Kopenhadze, gdzie był wtedy sekretarzem - Helena miała na nim akompaniować Irenie Dubiskiej w utworach Szymanowskiego - donosił Annie: „Dubiska bardzo zaniepokojona akompaniamentem Baby (co mi też dało gęsią skórkę nagle) - a już się słowo rzekło, z tego, co tu słyszę, widzę, że nie ma Baba ani za grosz techniki, jak wobec tego wyjdzie La Fontaine d'Aréthuse, to nie wiem”. Także śpiew Heleny nie oczarował wówczas pisarza: „Baba śpiewała mi dzisiaj pieśni Chabriera, nie masz pojęcia, jakim głosem, wstyd mi było strasznie służby, która się pewnie zachodziła ze śmiechu [...]. Zresztą zdaje się babsko zadowolone, śpi jak suseł, a ćmaka jak bóbr"10. Iwaszkiewicz nie był oczywiście konsekwentny; trzy dni po niepokojach o losy Aretuzy stwierdzał: „Kazela doskonale akompaniuje Myszy [z cyklu pieśni Szymanowskiego Rymy dziecięce], widać, że się nauczyła i to tak świetnie brzmi, niby monotonny akompaniament, a ciągle się zmieniający w nastroju stosownie do słów"11.

Wracając do Paryża: „w sferach muzycznych [Casella] znała dosłownie wszystkich"12. Jak dodaje Iwaszkiewicz w często cytowanym ustępie Książki moich wspomnień, ambicją Heleny „było obracanie się wśród najbardziej interesujących artystów swego czasu. Sama była w ciężkich warunkach materialnych, w ubóstwie prawdziwie paryskim, mimo to znała prawie pół Paryża i rzeczywiście mogła wprowadzić do bardzo interesujących środowisk"13. Tryb życia Caselli chyba nie do końca jednak był sprawą wyłącznie ambicji czy aspiracji, czyli tego, co - jak przypuszcza Iwaszkiewicz - mogłoby się jej "szalenie podobać, de jouer un rôle"14, i co każdy przecież lubi, nie wyłączając Iwaszkiewicza. Należała bowiem do osób bezinteresownie oddanych sztuce, żyjących sztuką (jej pasja nie kończyła się zresztą na muzyce, ale obejmowała także literaturę, teatr, a nawet film, o czym świadczy zachowana korespondencja).

Helena „żyła dla muzyki"15, pochłaniała ją bez opamiętania - i jako muzyk, często zupełnie „domowy”, dla samej siebie, nie dla publiczności („Gramy

9 W liście do żony z 16 sierpnia 1934 r. - A. i J. Iwaszkiewiczowie Listy 1932-1939, oprac. M. Bojanowska, E. Cieślak, Czytelnik, Warszawa 2014, s. 551.

W liście do żony z 4 sierpnia 1934 r. - tamże, s. 529.

W liście do żony z 19 sierpnia 1934 r. - tamże, s. 556.

R. Jasiński Zmierzch starego świata. Wspomnienia 1900-1945, WL, Kraków 2006, s. 353.

J. Iwaszkiewicz Ksiq̨żka moich wspomnień, Czytelnik, Warszawa 1975, s. 218.

W liście do żony z 23 lipca 1934 r. - A. i J. Iwaszkiewiczowie Listy 1932-1939, S. 502.

Określenie Felicji Lilpop-Krance (Powroty, red. P. Kądziela, Więź, Warszawa 2013, s. 129). 
zapamiętale na dwa fortepiany [z Dickiem Amesem, amerykańskim przyjacielem Szymanowskiego]. [...] Cieszy mnie dalsze poznawanie Mozarta - po sonatach, dwie cudowne Fantazje, bardzo krótkie i obydwie w f-moll"16), i jako słuchaczka, relacjonująca później bliskim wszelkie wydarzenia paryskiego muzycznego dnia, jako że „nie opuszczała żadnego koncertu, a już na pewno takich, na których wykonywano polskie dzieła"17. Była przy tym osobą o wyrobionym smaku; w świetle listów jej opinie jawią się jako autonomiczne i inspirujące, świadczą też o sporej otwartości (większej chyba niż w wypadku doktrynerskich niekiedy Iwaszkiewiczów). „Zatem Milhaud pisała np. o związkach Grupy Sześciu z music-hallem - również zaprodukuje się w «banale», który staje się chyba hasłem dnia. Czy Pan [Szymanowski] sobie przypomina swój dialog z Poulenkiem na temat oklepanych frazesów - już prawie sprzed dwóch lat? Nawet Satie nie towarzyszy już im w tym wstecznym biegu. To wszystko jest takie czcze...”18. „Gdy chodzi o wybitne nowości - relacjonowała z kolei Szymanowskiemu w październiku 1923 roku - Oktet Strawińskiego na instrumenty dęte, bardzo mocny i piękny utwór, Koncert skrzypcowy Prokofiewa jest bardzo przyjemny do słuchania, ale bardzo powierzchowny"19. „Jakież wyczucie rytmu, muzyki w sensie ogólnym oraz tańca mają ci ludzie! - pisała natomiast o „rewii murzyńskiej”. - Był tam jeden wspaniały tancerz, a przez moment jedynym akompaniamentem były tylko głuche uderzenia perkusji i parę akordów fortepianu - muzyka, która zdawała się powstawać z jego tańca. To było wspaniałe"20. Inny jeszcze przykład z listów do Szymanowskiego: „Wczoraj wieczorem po prostu wpadłam we wściekłość. W swoim liście wspominał Pan o Mawrze. Pan wie, że myślimy to samo - no, ale co Pan powie na te «pod-Mawry», jakimi nas karmią? «Dzieło naszego najmłodszego geniusza» Henri Sauguet - oczywiście nawet bez zalet formalnych Mawry. Tymczasem Milhaud i inni przyrównują to do Mozarta..."21. Z kolei różnica zdań między Casellą a Iwaszkiewiczem

16 Casella w liście do Szymanowskiego z 17 lipca 1924 r. - K. Szymanowski Korespondencja, t. 2, CZ. 2, S. 136.

17 F. Lilpop-Krance Powroty, s. 129.

18 W liście do Szymanowskiego z 16 marca 1924 r. - K. Szymanowski Korespondencja, t. 2, cz. 2, s. 60 . W liście z 26 października - tamże, t. 2, cz. 1, s. 664 .

W liście do Szymanowskiego z 11 listopada 1925 r. - tamże, t. 2, cz. 2, s. 395.

W liście z 28 kwietnia 1924 r. - tamże, s. 97. 
na temat Les biches Poulenca („paskudztwo [...] ona to lubi”22) prowokuje być może właśnie do pytania: zgadnij, kotku, kto tu lepiej słyszy? Casella potrafiła też - mimo bezgranicznego podziwu dla Szymanowskiego i jego muzyki - różnicować swoje oceny twórczości wielbionego kompozytora: „Ravel był i podziwiał [III] Symfonię. Ja uważam, że jest cudowna w formie, idee są bardzo piękne, instrumentacja również, ale jeszcze raz zaznaczam, że jest mniej osobista niż [I] Koncert [skrzypcowy], może też nie jest tak bogata w inwencję"23. Umiała również docenić młody, nawet jeśli chropawy jeszcze, talent - jak w wypadku Piotra Perkowskiego, i to nie tylko z tego powodu, że podobał się jej jako mężczyzna: „widziałam dopiero trzy pieśni Perkowskiego. Akompaniament jest niezręczny, utwory są jednak pełne wdzięku i zapewniam Pana [Szymanowski], że mnie nie rozczarowały. Odnoszę wrażenie, że świadczą o talencie, któremu brak jeszcze tego, czego można się nauczyć, ale któremu nie powinno zbraknąć pomysłów" 24 .

O wykształceniu muzycznym Caselli nie wiemy nic konkretnego, poza tym, że ze środowiskiem muzyków była zaznajomiona od wczesnej młodości. W 1907 roku poślubiła w Paryżu Alfreda Casellę; w 1919 między małżonkami nastąpiła separacja, a dwa lata później związek został oficjalnie rozwiązany, jednakże Helena utrzymała z byłym mężem-kompozytorem przyjacielskie stosunki. Blisko przyjaźniła się z Ravelem ${ }^{25}$, aktywnie zaangażowana w drugiej dekadzie XX w. w działalność wspomnianego Société musicale indépendente $^{26}$; nazwisko Caselli, w kontekście bogatej korespondencji z autorem Godziny hiszpańskiej, pojawia się we wszystkich jego monografiach. Zachowała się także korespondencja Heleny m.in. z Poulenkiem, Nadią Boulanger czy Gian Francesco Malipiero. Po Wielkiej Wojnie przylgnęła do kręgu czasopisma „La revue musicale”, założonego przez Henry'ego Prunières'a w 1920 roku $^{27}$ (sporadycznie udzielała się na jego łamach jako tłumaczka

Iwaszkiewicz w liście do Szymanowskiego z 4 lutego 1925 r. - tamże, s. 260.

W liście do Iwaszkiewiczów z 24 czerwca 1925 r. - tamże, s. 323-324.

W liście do Szymanowskiego z 18 listopada 1925 r. - tamże, s. 399.

Listy Ravela do Caselli zostały opublikowane - zob. M. Ravel Lettres de Maurice Ravel à Hélène Kahn-Casella et à Alfredo Casella, „Cahiers Maurice Ravel” 1985 no 1, s. 59-111.

Było to niezależne stowarzyszenie muzyczne założone przez Ravela, Faurégo, Charles'a Koechlina i Florenta Schmitta (w 1910 roku) jako przeciwwaga dla konserwatywnego Société nationale de musique; Alfredo Casella pełnił funkcję sekretarza stowarzyszenia.

Znaczenie tego periodyku dla kultury muzycznej międzywojennego Paryża charakteryzuje Teresa Chylińska (Śladami Szymanowskiego w Paryżu, „Ruch Muzyczny” 1982 nr 9, s. 4). 
z włoskiego ${ }^{\mathbf{2 8}}$ ). Tam, 8 kwietnia 1922 roku - na wieczorze po recitalu Bartóka - poznała Karola Szymanowskiego ${ }^{29}$. Stała się wkrótce wielbicielką jego muzyki, osobowości i niestrudzoną - można by rzec bez wielkiej przesady - menedżerką kompozytora w Paryżu, niemalże oficjalną przedstawicielką jego interesów we Francji (choć wspierała również innych muzyków, m.in. wspomnianego Perkowskiego czy Stanisława Szpinalskiego, i to czyniąc zabiegi nie tylko związane z promocją samej muzyki, ale dotyczące nierzadko spraw najzwyczajniej finansowych ${ }^{30}$ ). Casella „tak wrosła w polskie środowisko, że częściej [...] na jej jour fixe i wieczorach muzycznych mówiło się po polsku niż po francusku"31.

„Nie dowiemy się - pisze Teresa Chylińska - co bardziej: muzyka czy jej twórca, olśniło i oczarowało Helenę przy pierwszym spotkaniu z Szymanowskim - w każdym razie stał się on prawdziwą przygodą jej życia"32. Przygodą - o czym za chwilę - ale i zobowiązaniem. Korespondencja obojga przepełniona jest bowiem „interesami”33 - pomysłami Heleny co do promocji muzyki ukochanego kompozytora w Paryżu, informacjami o nadarzajaccych się okazjach i interesujących muzykach - potencjalnych wykonawcach, prośbami o materiały nutowe i szczegółowymi pytaniami o detale kompozycji, zapisu czy wzbudzającej wątpliwości Heleny redakcji (co przy okazji odsłania jej warsztat profesjonalistki). Szymanowski odpowiada mniej regularnie (nieustannie usprawiedliwiając opóźnienia); do „interesów” odnosi się obszernie, aczkolwiek można niekiedy mieć wrażenie, że pomoc Caselli traktuje instrumentalnie i - jak sam pisze - faute de mieux ${ }^{34}$. (Tłumaczy jednak również - czy szczerze? - „wszystko to, co już napisałem, [...] nie istnieje dla mnie więcej. [...] Dzieło ukończone - to w sumie zewłok, który odrzuca się, żeby

28 Zob. np. M. Mila Ottorino Respighi, trad. de l'italien par H. Kahn Casella, "La revue musicale” 1933 no 135 , s. 250-256.

Zob. komentarz Chylińskiej do listu Bartóka do matki z 15 kwietnia 1922 r. - K. Szymanowski Korespondencja, t. 2, cz.1, s. 357-358. Pierwszy zachowany list Heleny do kompozytora pochodzi jednak dopiero z 22 października 1922 r. - zob. tamże, s. 438-439.

30 Zob. np. A. i J. Iwaszkiewiczowie Listy 1922-1926, s. 529, 581.

F. Lilpop-Krance Powroty, s. 128.

T. Chylińska Wstęp, w: K. Szymanowski Korespondencja, t. 2, cz.1, s. 9.

Zob. np. list Caselli do Szymanowskiego z 20 stycznia 1924 r. - tamże, t. 2, cz. 2, s. 18-20.

W liście do Augusta Iwańskiego z 24 czerwca 1925 r. - tamże, s. 322. 
zrobić miejsce dla nowo urodzonego"35). Czasem jednak ogrom wysiłków Heleny dostrzega: „mam ciągle listy od poczciwej Caselli! Ona jednak robi tam dla mnie, co może - i w tym roku dość dużo mnie grali w Paryżu, i jakoby z powodzeniem"36. Bo też rzeczywiście działania Caselli - kropla drążąca skałę - odegrały wielką i rzeczywistą rolę w zapoznawaniu Paryża z dziełem i osobą Szymanowskiego. Dzięki niej doszło np. do wykonania III Sonaty ${ }^{37}$. Helena była również zaangażowana w przygotowania cyklu polskich koncertów towarzyszących Exposition internationale des arts décoratifs et industriels modernes w czerwcu 1925 roku, a zwłaszcza - w kompozytorski koncert Szymanowskiego w Maison Gaveau (23 czerwca), podczas którego doszło do paryskiego prawykonania IIISymfonii ("módlcie się, żebym znalazła tenora..." - pisała miesiąc wcześniej do Iwaszkiewicza $\left.{ }^{38}\right)$.

„Interesy” - to jedno, uczucia i przyjaźń - drugie. Szymanowski w korespondencji z Casellą uchyla maski, co nie zdarzało mu się wcale często. „Pozwala sobie - jak pisze Chylińska - [...] na luksus słabości, kaprysu, żalu nad sobą"39: „jestem zgorzkniały i zgryźliwy [...]. Staję się [...] wirtuozem i literatem zamiast być po prostu kompozytorem! To zupełnie absurdalne!!"40; skarży się na neurastenię i koszmar krajowego środowiska muzycznego (zwłaszcza w okresie pracy w Konserwatorium, a później - w Wyższej Szkole Muzycznej w Warszawie). Helena go wspiera: „Pan wcale nie jest żadnym zgorzkniałym, podstarzałym chłopcem! Pan jest wielkim artystą, najbardziej ze wszystkich, jakich znam, uwrażliwionym na poezję i dlatego właśnie czuje się Pan, jak Pan powiada, «na marginesie». Niewiele osób jest w stanie Pana zrozumieć, a ja myślę o tym mieszczańskim czerepie..."41. Wspiera, a czasem też, z właściwą sobie subtelnością, przywraca do pionu: „Pański ostatni list

\footnotetext{
W liście do Caselli z 13 lutego 1924 r. - tamże, s. 33.

W liście do Zofii i Pawła Kochańskich z 10 stycznia 1924 r. - tamże, t. 2, cz. 1, s. 721.

W liście z 28 listopada 1923 r. pisała do Szymanowskiego: „właśnie usłyszałam Pańską III Sonatę i jestem zbyt wstrząśnięta, zbyt wzruszona, by móc robić cokolwiek innego, niż Panu o tym powiedzieć [...]. Poprosiłam więc Smetterlinga, żeby we wtorek zagrał tę Sonatę w «Revue Musicale»" (tamże, s. 683-684).

W liście z 26 maja 1925 r. - tamże, t. 2, cz. 2, s. 305.

T. Chylińska Wstęp, s. 9.

Szymanowski w liście do Caselli z 22 listopada 1923 r. - K. Szymanowski Korespondencja, t. 2, cz. 1, s. 677 .

W liście z 30 listopada 1923 r. - tamże, s. 686.
} 
zdradzał humor dość cierpki, ale muszę powiedzieć, że wolę u Pana nastrój zaczepny i kłótliwy, w sumie aktywny, niż obojętność, w jaką niekiedy Pan popada"42. Przejmujące wrażenie wywierają listy Caselli z ostatniego okresu życia kompozytora. Helena próbuje Karola rozweselić i rozruszać, zdobywając się na raczej dla siebie niecharakterystyczne zabawne paplanie, ploteczki ze świata, jakby sytuacja nie była poważna. „Proszę się ze mnie nie wyśmiewać - pisze - płakałam wielkimi łzami, kiedy czytałam posłanie Edwarda [VIII o abdykacji]. Moja praczka powiedziała: «Więc kiedy jest się królem, to nie można robić wszystkiego, co się zechce?» Było to z pewnością dla niej przewróceniem porządku świata"43. Posyła także Szymanowskiemu, mimo trudnej sytuacji materialnej, leki. „Niech Pan nie opowiada o mojej «dobroci»; nie potrzeba dobroci, kiedy jest tyle przyjaźni"44 - wyjaśnia kompozytorowi już w pierwszych latach znajomości.

Dobroć Heleny - poczciwość, jak określali to jej przyjaciele - „złote serce, uczynność, uprzejmość [...] nie miały [jednak] granic" ${ }^{\text {. }}$. „Nie masz pojęcia o dobroci i poczciwości Caselli - piał Iwaszkiewicz do żony w lutym 1925 roku z Paryża ${ }^{46}$. - Przysyła mi w te dnie, co się nie widujemy, malutkie liściki, pełne czułości i interesów. Dzisiaj przesłała mi bilet na koncert [Ricardo] Viñesa [hiszpańskiego pianisty] i upomnienia, abym się za bardzo nie męczył..."47. A w innym miejscu: „moja droga, cóż to za poczciwina ta Casella, ledwie jej nadmieniłem, że jestem w kłopotach pieniężnych, przyleciała wczoraj z dwustu frankami do mnie. Koniecznie, żebym wziął, wiesz, że jeszcze ze strony żadnego przyjaciela, nawet najserdeczniejszego, nie spotkała mnie taka uprzejmość i serdeczność. To naprawdę bardzo dobra osoba"48. Tej dobroci było jednak tak wiele, że już po dwóch tygodniach pobytu w Paryżu

42 W liście z 22 grudnia 1923 r. - tamże, s. 708.

W liście z 11 grudnia 1936 r. - tamże, t. 4, 1932-1937, cz. 6, 1936**/1937, PWM, Kraków 2002, s. 91.

W liście z 21 marca 1924 - tamże, t. 2, cz. 2, s. 63.

J. Iwaszkiewicz Książka moich wspomnień, s. 218.

Czyli wkrótce po poznaniu Heleny. Iwaszkiewicz wyjechał do Paryża pod koniec stycznia 1925 roku na dłuższy pobyt; planował m.in. studia w École des langues orientales (z planów tych nic nie wyszło). Dzięki Caselli udało mu się jednak nawiązać wiele interesujących znajomości i zaznać bogactwa francuskiego życia kulturalnego. Wnikliwie omawia to i interpretuje Radosław Romaniuk (Inne życie. Biografia Jarosława Iwaszkiewicza, t. 1, Iskry, Warszawa 2012, s. 326 i n.). 
pisarz żartobliwie wzywał Annę: „przyjeżdżaj czym prędzej, bo nas tu wezmą za parę kochanków"499.

No, właśnie! Było jej tyle, że obdarowani zaczynali tę dobroć deprecjonować, traktując jak coś oczywistego, a samą Helenę - uznawać protekcjonalnie za "zabawną i poczciwą kobitę"50 lub - by użyć słów Marii Iwaszkiewicz - za typ „skromnej, poczciwej nudziary”"51 (co więcej mówi chyba o naturze ludzkiej niż o samej Caselli). Można by tu przytoczyć anegdotę córki Iwaszkiewiczów: jakąż miał minę Szymanowski, znużony towarzystwem Caselli w czasie jej pobytu w Zakopanem w 1927 roku, kiedy wreszcie wyprawił przyjaciółkę na daleki spacer z małżeństwem Rytardów - i zaraz ujrzał ją z powrotem, bo za obejściem pokąsał Helenę pies... Wątek ten nie jest taki znowu tylko lekki i anegdotyczny. Czytelnik listów Iwaszkiewiczów lub Szymanowskiego ma bowiem nieprzyjemne wrażenie, że Casella traktowana jest poniekąd przez przyjaciół jak mebel, który choć stary i opatrzony, jest zawsze do dyspozycji. Zwłaszcza Iwaszkiewiczowie odreagowują niekiedy na Helenie, oczywiście za jej plecami, własne frustracje i kompleksy. Kiedy Iwaszkiewicz pisze: „nie cierpię tonu wyższości paryskiej, który ma Baba w stosunku do wszystkiego, co nie jest francuskie, ten brak humilité jest oburzający właśnie u niej; ale ostatecznie co mi to szkodzi, nic mnie w gruncie rzeczy jej charakter nie obchodzi, a jak Ci powiedziałem, babsko boi się mnie..." ${ }^{22}$ - to nie mieści się sam we własnej skórze, pragnąc bezskutecznie jakiejś autre chose, o której pisze do Anny ${ }^{53}$ (ten wątek, w różnych odcieniach, nieprzypadkowo czyni Radosław Romaniuk osią biografii pisarza! $\left.!^{54}\right)$.W pewnym stopniu instrumentalny stosunek do Caselli przekłada się także na współczesne badania nad Szymanowskim. Dlatego też Teresa Chylińska sugerowała mi, że „poczciwa Helena” za swoje „dobre serce" otrzymała wystarczającą nagrodę w postaci przyjaźni, którą darzyli ją najwięksi ${ }^{55}$, nie zauważając jednak, że w relacji z nimi - np. w korespondencji

\footnotetext{
W liście z 15 lutego 1925 r. - tamże, s. 273.

Jak to zrobił sam Iwaszkiewicz w liście do żony z 26 marca 1926 r. - tamże, s. 529.

Z rozmowy przeprowadzonej przeze mnie w maju $2006 \mathrm{r}$.

W liście do żony z 19 sierpnia 1934 r. - A. i J. Iwaszkiewiczowie Listy 1932-1939, s. 556.

Np. w liście z 16 sierpnia 1934 r. - tamże, s. 552.

R. Romaniuk Inneżycie.

W korespondencji prywatnej z 2007 r.
} 
z Szymanowskim - Casella jawi się jako partner równoprawny, o ile w ogóle nie wypada ciekawej niż kompozytor.

Ewolucja jego stosunku do Caselli nastąpiła zresztą dość szybko, już po roku znajomości. 14 lipca 1923 roku Szymanowski pisał do Zofii i Pawła Kochańskich: „po Waszym wyjeździe spędziłem jeszcze kilka szarych dni w Paryżu. Musiałem poodwiedzać różnych zaniedbanych przez Was ludzi. Casellicha naturalnie co dzień mię nawiedzała, biedactwo. Nudna, ale naprawdę to poczciwe kobiecisko i bardzo oddana"56. Miewał świadomość nielojalności: „nie mów - pisał do Zofii Kochańskiej - poczciwinie Caselli, że miałaś list ode mnie. Ona naprawdę taka poczciwa, a ja świnia - we wszystkich kłopotach coś 4 miesiące do niej ani słówka!!"57.

Powody? Była Casella żywym człowiekiem, kobietą z krwi i kości, niewolną od słabostek, czasem - rzadko - od drobnych humorów, wrażliwą na urodę przystojnych mężczyzn ${ }^{58}$. „Cóż to za dziwna baba z tymi amorami!” - wyrokował Iwaszkiewicz z pozycji swoich trzydziestu dwóch lat (wobec czterdziestu dziewięciu Heleny) ${ }^{59}$, nie podejrzewając jeszcze nawet, jak sam będzie się miotał trzydzieści lat później. Ale prawdziwą namiętnością Heleny był oczywiście Karol - Carissimo, nawet jeśli w oczach obserwatorów ta miłość wydawała się osobliwa. Notowała Anna Iwaszkiewicz: „Dziwna jest taka miłość: trwa to już od pięciu lat i roztacza kręgi coraz szersze przez miłość do Karola kocha i jego całą rodzinę (której nie zna, oprócz Stasi), nas, wszystkich młodych artystów polskich, których otacza czasem wprost macierzyńską opieką, Polaków i Polskę w ogóle. Stosunku Karola do niej właściwie nie rozumiem, bo z tego, co ona nieraz mówi, wnioskować można o ich wielkiej zażyłości, zresztą wiem, że dużo ze sobą korespondują, z drugiej strony, nieraz Karol nawet nam mówił ze zniecierpliwieniem o niej, o scenach, jakie potrafiła mu robić, kiedy gdzieś się jej wymykał itd. Dziwi mnie to wszystko tym bardziej, że ona nieraz z uśmieszkiem wspomina o gu-

56 K. Szymanowski Korespondencja, t. 2, cz. 1, s. 612.

57 W liście z 5 czerwca 1926 r. - tamże, t. 2, cz. 2, s. 462.

58 Wspominałem już o Perkowskim, który jednak podsycał - jak sugeruje Iwaszkiewicz - zainteresowanie Heleny. W liście do żony z 24 marca 1926 r. pisarz ironizuje: „Piotruś jak cielę (bo to niby prawdziwe) daje się prowadzić na tym sznureczku i dobrze im z tym obojgu" (A. i ). Iwaszkiewiczowie Listy 1922-1926, s. 522).

59 Tamże - widząc w niej jednak czasem kobietę, jak na soirée musicale w paryskim Institut de la coopération intelectuelle (25 marca 1926), w „ślicznej sukni ceglastej ze złotem” (w liście do żony z 26 marca 1926 r. - tamże, s. 529). 
stach Karola, który przed nią widocznie się z tym nie kryje. [...] Że też ona, znając Karola, nie zdaje sobie sprawy z tego, że o ile go może zająć kobieta, to musi być młoda i ładna, a nie mocno podstarzała, poczciwa, zakochana w nim do nudziarstwa"60. Z tego powodu kompozytor nieraz skarżył się na ciężar przyjaźni z Casellą: „Dni następne po Twoim wyjeździe - pisał do siostry Zofii we wrześniu 1931 roku - aż do wczoraj wieczór, kiedy nastąpiło «rozwiązanie», były ponure! C - coraz tragiczniejsza i liryczniejsza, niczym Hekuba czy Klitemnestra. Przykro mi, że to piszę i że takie w gruncie poczciwe babsko tak umie sadła za skórę zalać"61. Trzeba powiedzieć otwarcie, że czynił to niekiedy w formie urągającej nieodzownemu warunkowi przyjaźni - mianowicie lojalności: „Jest w niej coś z pokornego, suczego nahalstwa i to mię tak w niej wścieka" - pisał do siostry Stanisławy w lutym 1937 roku (à propos planów Heleny przyjazdu do Grasse) ${ }^{62}$; „Od kilku dni niestety przyjechała tu [do St. Jean de Luz] poczciwa zresztą jak zawsze Casella i tak mnie potwornie zanudza swoją bezsensowną i nietaktyczną adoracją, że jestem ciągle sur le point de devenir grossier. Podobnego crampon'u nigdy w życiu nie widziałem, choć znam ich porządną kolekcję"63.

\section{***}

Casella - mimo obfitości zachowanych materiałów źródłowych - pozostaje nadal w cieniu: „była osobą wyjątkową, choć właściwie bardzo niewiele o niej samej wiadomo"64. Częściowo - z winy badaczy, którzy skupili się na "gigantach", traktując ich otoczenie instrumentalnie.

Przedmiotem kontrowersji była sprawa dość podstawowa: data urodzin, opatrywana zawsze znakiem zapytania. Wymieniano zwykle rok „ok. 1877” - tak sugerowała najbliższa prawdy Chylińska - a nawet $1889^{65}$. W efekcie

60 W Dziennikach pod datą 6 września 1927 r. - A. Iwaszkiewiczowa Dzienniki i wspomnienia, S. 210-211.

61 W liście z 7 września 1931 r. - K. Szymanowski Korespondencja, t. 3, cz. 3, 1930, 1931, s. 627.

62 W liście z 5 lutego 1937 r. - tamże, t. 4, cz. 6, s. 216.

63 W liście do siostry Zofii z 14 sierpnia 1925 r. - tamże, t. 2, cz. 2, s. 351.

64 T. Chylińska Wstęp, s. 8-9.

65 M. Grydzewski, J. Iwaszkiewicz Listy 1922-1967, oprac. M. Bojanowska, Czytelnik, Warszawa 1997, s. 26, 
badań prowadzonych przeze mnie w listopadzie 2007 roku w Archives de Paris ustaliłem jednak, że Hélène Kahn-Casella urodziła się 8 maja roku $1876^{\mathbf{6 6}}$.

Przyszła na świat przy bulwarze Sebastopol jako córka urzędnika Émile’a Kahna (ur. 9 czerwca 1844 roku w Nancy) i Fanny z domu Salomon (ur. 13 października 1850 roku w Phalsbourg; Kahnowie pobrali się 15 lipca 1875 roku w Paryżu). Helena była więc Żydówką. Czy to ma znaczenie? Jak to w naszym kręgu kulturowym - zupełnie nie albo zdecydowanie tak (zależy, kto i po co pyta). Adolf Chybiński np. w liście do Juliusza Zborowskiego z 31 marca 1937 roku zauważa: „Wyobraź sobie: o śmierci K. dowiedziałem się dopiero wczoraj $\mathrm{z}$ «IKC»! Nie słucham radio [...]. Że też jednak - zawsze w życiu K. musieli do każdej sprawy przymieszać się Żydzi. Obok Stasi był przy jego śmierci obecny pan Gradstein (młody Żydek - kompozytor) [oczywiście Chybiński myli Leonię Gradstein z jej bratem Alfredem zamieszkałym w Paryżu - przyp. T. Chylińska]. Jakby na złość powstaje symbolika dziejów Karola, w których tyle sukcesów zawdzięczał Żydom. Nie szłoby to tak dobrze i szybko bez Kochańskiego, Rubinsteina i Fitelberga! A wydawcami byli Żydzi z Universal-Edition w Wiedniu, a p. Casella też Żydówka"67 ...

Helena była najstarsza z czworga rodzeństwa. Jej młodszy brat René, którego datę urodzenia także ustaliłem, urodził się rok później, 15 października 1877 roku, zaś siostry - znane w rodzinie Iwaszkiewiczów jako soeury, wzmiankowane w kilku edycjach źródłowych - Yvonne i Alice: odpowiednio w 1879 (tu nadal brakuje daty dziennej) i 1884 roku (18 stycznia). Alice Kahn żyła zresztą długo (zmarła 25 lutego 1979 roku w Paryżu); to w jej spuściźnie przetrwały listy Szymanowskiego, które następnie, dzięki Dominique Lambert (z domu Wormser) i Felicji Lilpop-Krance, znalazły się w Polsce ${ }^{\mathbf{6}}$.

W czasie I wojny światowej Casella wraz z mężem przebywała w Rzymie ${ }^{69}$ i Paryżu. Po rozwodzie (w 1921 roku) znalazła się w trudnej sytuacji

66 Zob. G. Piotrowski Francuska przyjaciółka Szymanowskiego - Hélène Kahn-Casella, „Ruch Muzyczny" 2008 nr 5, s. 30-32.

67 K. Szymanowski Korespondencja, t. 4, cz. 6, s. 308.

68 Chylińska - opisując historię pozyskania tych listów (Śladami Szymanowskiego w Paryżu (3), „Ruch Muzyczny” 1982 nr 11, s. 18-19) - podaje, że Dominique Lambert-Wormser (badaczka posługuje się taką formą nazwiska Lambert), "kuzynka” Alice Kahn, weszła w ich posiadanie po śmierci Alice, którą opiekowała się w „ostatniej chorobie”. Ustaliłem, że Dominique Lambert była spokrewniona z rodziną Caselli przez babkę ze strony ojca - Louise Wormser z domu Salomon, siostrę matki Heleny.

69 W pierwszej połowie r. 1916 - por. M. Ravel Letters de Maurice Ravel, s. 71-72. 
finansowej („widać, że bidę klepie, mieszka czort wie gdzie, 3 kwadranse jazdy metro" - pisał Iwaszkiewicz do Anny w styczniu 1925 roku $^{70}$ ) i zapewne także społecznej; zamieszkała w Neuilly, na rue d'Orléans pod numerem $22^{71}$. „Trudno by nazwać salonem mieszkanie Heleny Casella w Neuilly - pisała Lilpop-Krance. - Było nieduże, skromnie umeblowane, główną jego ozdobą - prócz fortepianu - były rozstawione gdzie tylko się dało fotografie przyjaciół i muzyków, wśród których zdjęcia Karola Szymanowskiego i rodziny Iwaszkiewiczów zajmowały niepoślednie miejsce"72.

Sytuacja materialna Heleny staje się przedmiotem dialogu z Szymanowskim bodaj tylko raz, w grudniu 1936 roku: „Chcę napisać Panu jeszcze to, o czym nikomu nie mówię, ponieważ to nie dla ludzi. Panu jednakże mówię wszystko, cokolwiek mnie dotyczy. Od chwili powrotu żyłam w straszliwych kłopotach natury finansowej - całkowite bezrobocie, pomoc mojej siostry jedynie, która wiele nie mogła. Przed trzema dniami - to tak jak w bajkach - odwiedził mnie jeden z moich kuzynów. Bardzo bogaty, od lat go nie widziałam. Powiedział, że parę słów moich sióstr pozwoliło mu zrozumieć moją sytuację, że wydało mu się to czymś niedopuszczalnym i udał się do mego brata, który nie jest zły, tylko niefrasobliwy i egoistyczny - i że wspólnie z nim i moją siostrą zabezpieczą mi środki do życia, na pewno bardzo skromnego, wolnego jednak od troski o jutro. Jeszcze są ludzie z sercem, Karolu Kochany. Jak Pan znowu przyjedzie, będę mogła zaprosić Pana na obiad!"73. Jest to interesujące także dlatego, że sytuacja sióstr Heleny - jak wynika z różnych listów, wspomnień oraz komentarzy Iwaszkiewicza - była znacznie lepsza. Udało mi się to trochę rozjaśnić dzięki poszukiwaniom archiwalnym dopiero w 2017 roku: Alice Kahn - znana jako Alice Mallet - była żoną wybitnego i wziętego

W liście Caselli z 20 grudnia 1936 r. - K. Szymanowski Korespondencja, t. 4, cz. 6, s. 120. Szymanowski - 29 grudnia 1936 r. - odpowiadał: „Nie potrafię wypowiedzieć, jak bardzo cieszę się z powodu zmiany w Pani życiu [...]. Pani wie, że niewiele osób tak dobrze może zrozumieć wagę tego, co się Pani zdarza. Nigdy nie miałem śmiałości poruszyć z Panią tego tematu, tym bardziej że zawsze była Pani taka skryta" (tamże, s. 148). 
architekta Roberta Malleta-Stevensa; obie siostry mieszkały w luksusowej (Iwaszkiewicz mówi: snobistycznej34) willi Saïd przy rue Pergolèse 68, która była rodzajem kolonii artystycznej (mieszkali tam m.in. Anatole France i Kees van Dongen).

Jak podaje Felicja Lilpop-Krance ${ }^{75}$, siostry Heleny, zwane w towarzystwie Moute [Alice] i Folette [Yvonne], „przeniosły się w czasie wojny do Nowego Jorku i, jak w Paryżu, prowadziły tam też dom otwarty"76. Wiadomo jednak również, że po kapitulacji Francji Casella mieszkała z nimi na południu kraju7. Zmarła 31 października 1952 roku w swoim mieszkaniu przy rue Mesnil $7^{\mathbf{7 8}}$.

Przez wiele lat prowadziłem bezskuteczne poszukiwania grobu Heleny w Paryżu (wierząc podświadomie w jakąś formę kontaktu z tymi, którzy odeszli, ale też nie godząc się na ich zapomnienie). Dopiero w lipcu 2017 roku zaangażowany w te poszukiwania Karol Szymański ustalił na miejscu, że Casella została pochowana 3 listopada 1952 roku na cmentarzu Montparnasse (kwatera nr 5, sekcja trzecia, rząd piąty - licząc od północy, grób nr 7 - od wschodu). Jej grób został jednak zlikwidowany w roku 1997, by ustąpić miejsca innym pochówkom...

A czemu la lumière? Helena - jak wspomina Maria Iwaszkiewicz - była gadatliwa, nie lubiła kończyć rozmowy. Kiedy tematy wyczerpywały się więc już zupełnie, chwytała rozmówcę: la lumière! - jakie światło!

Zob. komentarz pisarza do listu do żony z 16 sierpnia 1934 r. - A. i J. Iwaszkiewiczowie Listy 1932-1939 , s. 552.

To wlaśnie Lilpop-Krance przyniosła Caselli wiadomość o śmierci Szymanowskiego: „mnie wypadło pójść do Caselli, to było okropne, grała fałszywie na pianinie i nie słyszała dzwonka. Byłam takzdenerwowana, że chciałam się wrócić ode drzwi. Zabrałam ją potem do domu i dwa dni mieszkałyśmy razem" (Powroty, s. 367).

76 Tamże, s. 454.

77 Informację tę zawdzięczam dr Małgorzacie Zawadzkiej z Muzeum im. A. i J. Iwaszkiewiczów w Stawisku.

78 Akt zgonu nr 1764 Heleny Kahn-Cazella (sic!), sporządzony 1 listopada 1952 r. w Maire du 16e arrondissement (odpis w moim posiadaniu). Casella mieszkała pod tym adresem już w okresie wojny francusko-niemieckiej; por. list Lennoxa Berkeleya do Nadii Boulanger z 12 kwietnia 1940 r. - Lennox Berkeley and Friends. Writings, Letters and Interviews, ed. by P. Dickinson, Boydell Press, Woodbridge 2012, s. 67. 


\section{Abstract}

\section{Grzegorz Piotrowski}

UNIVERSITY OF GDAŃSK

ACADEMY OF MUSIC IN GDAŃSK

La Lumière: Hélène Casella, Karol Szymanowski's Friend in France

The pianist and accompanist Hélène Casella (1876-1952) was one of the most popular figures of the Parisian music scene in the 1920s and 30s. Engaged in the activities of the Société Musicale Indépendante and La Revue Musicale, she met Karol Szymanowski in 1922 and soon became not only a great admirer of his music but also a personal friend. She promoted his work in Paris and supported artists who were close to him, for instance Jarosław Iwaszkiewicz, who would later express his appreciation for her emotional and intellectual depth. Based on archival research Piotrowski portrays Casella and her contributions to Polish culture.

\section{Keywords}

Hélène Kahn-Casella, Karol Szymanowski, Jarosław Iwaszkiewicz 